\section{States compete with novel bait \\ Washington}

STATE governments have become key but inconspicuous players in the promotion of high-technology industries. In an intense competition to attract high-technology investment, 27 state governors have appointed boards and commissions to upgrade local research universities, build science parks and conjure up venture capital for private or academic entrepreneurs who can turn scientific ideas into marketable products.

Many of these commissions have become permanent parts of their state government. Early this year, Minnesota established a science and technology office to advise the governor. Iowa has set up a high-technology council with a research budget of $\$ 2$ million. North Carolina recently breathed new life into its slumbering science and technology board. And the state of New York has told its science and technology council, chaired by the state commissioner of commerce, to implement an ambitious plan to build up high technology in the region.

Although they were once viewed with scepticism, science councils at state government level appear to have become essential for states that want to attract hightechnology industries. Earlier this year, 27 states competed to persuade the new $\$ 50$ million Microelectronics and Computer Corporation (MCC) to make its home in their state. According to MCC chief executive Admiral Bobby Inman, the decision went to Austin, Texas, because a state board mobilized political, financial and academic leaders and put together a package of inducements MCC could not refuse.

As part of the package, the state will sink large sums in the University of Texas at Austin to build up its strength in computer science. There will be $\$ 15$ million over three years for endowed chairs and additional professorships and $\$ 750,000$ a year for 10 years in grants for computer science graduate students. The state is offering MCC a new building on university-owned land at a minimal rent, low fixed-interest home loans for MCC staff and a jobfinding service for their spouses.

Texas is only an inch ahead of other states working aggressively to increase their stake in high-technology. New York, which first set up a science and technology council in the $1960 \mathrm{~s}$, is spending heavily to implement a high-technology master plan, devised by the Battelle Laboratories (Columbus), that will boost the state's existing strengths in electronics, information science, medicine and biological products.

Under one programme, the state is supporting university and non-profit laboratories whose work can be rapidly commercialized. The State University of New York (SUNY) at Stony Brook, for example, is receiving money to find industrial collaborators for its work on the production of monoclonal antibodies. Meanwhile, a state-funded corporation for innovation development gives start-up capital to small high-technology ventures. A typical recent investment was $\$ 100,000$ for Laboratory Microsystems, a Troy company that applies microcomputers to

At the centre of New York's plan is the designation of "centres of advanced technology" to nurture links between universities and companies. Advised by the National Academy of Science, the state has already spent nearly $\$ 2$ million on four centres at local universities: Cornell (biotechnology), Rochester (optics), SUNY (medical diagnosis) and the Polytechnic Institute of New York (telecommunications).

In Massachusetts, where new hightechnology industries have helped to arrest two decades of decline in conventional industries, a state technology park corporation is raising funds for a network of facilities that can be used by universities and private industry to train students and employees. The first facility, a $\$ 40$ million microelectronics centre, will receive half its money from the state and half from a consortium of private companies and universities.

Like New York, Massachusetts has established a technology development corporation which tracks down venture capital for new companies or invests its own money in young companies. Last year, the corporation invested \$150,000 in Aspen Technology, a computer software company formed by members of the faculty at the Massachusetts Institute of Technology.

North Carolina, runner-up in the competition for $\mathrm{MCC}$, has recently imlaboratory instruments.

\section{Brighton}

ALLYING itself to the fashionable idea that more should be done to strengthen links between academic scientists and industry, the British Association for the Advancement of Science (BA) has taken steps to involve more industrial companies in its activities. A Science and Industry Committee has been established, under the chairmanship of president for this year, Sir Alistair Pilkington, a prominent industrial scientist. There is also a new class of corporate membership, which has so far attracted 22 companies, including several banks.

To forge links with industry, $\mathrm{Mr}$ Bernard Dyer has joined the association's full-time staff from Imperial Chemical Industries Ltd. He will try to persuade as many science-based industries as possible to join the association, each paying a minimum fee of $£ 500$.

Mr Dyer will be approaching many com- proved coordination between its already strong research universities and hightechnology companies. By setting up a microelectronics centre and a biotechnology centre, the state plans to harness existing research resources so they are better able to compete for federal grants and private investment. At present, the biotechnology centre is raising industrial money for a research and teaching consortium in plant molecular biology. It is also coordinating a three-university proposal for National Science Foundation funds to conduct research on monoclonal lymphocyte technology.

The National Governors Association, which has set up a task force on technological innovation, has counted 13 states with active plans to develop research parks or high technology zones modelled on North Carolina's Research Triangle or the Stanford Industrial Park in California. Six states have set up corporations to raise venture capital for high technology firms. Georgia, New York and Pennsylvania have created "research incubators" university-linked facilities which offer inexpensive accommodation and technical services to a small number of starting-up businesses.

The surge of competition has not always helped state governments. The Office of Technology Assessment says that in their struggle to woo investors, some states have of fered to give new factories up to ten years relief from property taxes.

Lately, however, there have been signs that this kind of competitive bidding is falling from favour. A forthcoming report by the National Governors Association points out that no state can capture more than a small share of high technology firms. Future efforts, it says, should concentrate on supporting local research institutions and nudging existing industries in the direction of new technologies. Peter David

\title{
BA makes overtures to industry
}

panies directly, but he hopes that smaller concerns will come knocking at his door. Through BA, companies will stand to become aware of technological developments and how these might be applied in specific circumstances. Later it may be possible to build up a register of academic and industrial consultants to advise on the use of new technologies.

The scheme may also act as a public relations exercise for industry in general. $\mathrm{Mr}$ Dyer points out that many schoolchildren may develop a lasting interest in science through membership of BAYS, the association's division for young people. If links with industry permeate to their level, the image of industry may be considerably enhanced. Last but perhaps not least, a more active role for industry may help to improve the parlous state of BA's own finances.

Tim Beardsley 